\title{
A CONTRIBUTION TO THE FERN FLORA OF FRENCH GUIANA
}

\author{
BY \\ K. U. KRAMER \\ (Botanical Museum and Herbarium, Utrecht)
}

(Received Sept. 3, 1954)

In recent times very little has been published on the fern flora of French Guiana. In 1918, R. Bonaparte published a list of fern specimens, collected chiefly by Leprieur and Mélinon (p. 365: Guyane française, plusieurs collecteurs, herbier du Prince Bonaparte; apart from some scattered notes in other volumes of Notes Ptéridologiques); Posthumus's records of ferns from that region, which are included in his work on the ferns of Surinam (1928), were partly based on Bonaparte's work, but comparatively little new material had been added to the existing collections. Consequently, when Mme M. Tardieu-Blot informed me that the Paris herbarium contained some unidentified collections of Pteridophytes from that region, I accepted willingly her offer to study them.

In this paper are enumerated new or critical or in some other respects interesting records of ferns from the material concerned. It is regrettable that most collections do not possess indications of precise localities, or even lack collectors names, numbers, or both; it is supposed that most of these specimens have been collected by Leprieur.

\section{Hymenophyllaceae}

Trichomanes diversifrons (Bory) Mett.

Leprieur (?) 37. In my opinion this species, as commonly understood, is still an aggregate, even if the next species is segregated.

Trichomanes trollii Bergdolt

Without collector's name or number. Previously known from British Guiana, Surinam, and Bolivia.

\section{Polypodiaceae}

Adiantum cristatum L.

Three fronds, without data, only labelled Guyane française or Cayenne. Not previously known from the Guianas. 


\section{Adiantum killipii Maxon \& Weatherby}

The material at my disposal contained a duplicate of one of the collections cited as cotypes: Leprieur s.n. ("In declivis montium guyanae centralis Oyapok superius, juin 1823"), bearing the name Adiantum intermedium Swartz. It is somewhat aberrant by the smaller size of the fronds and segments and by the sori occupying only the upper and outer margin of the roughly parallelogrammic pinnules; also the stiff, curved or flexuose fibril-hairs of the lower surface are absent on several (esp. sterile) segments, being evidently rather caducous. The same is true for the hairs on the reflexed parts of the lobes.

Additional specimens: Leprieur 145, without loc.; Surinam: Hostmann 710 a $[\mathrm{L}]$, without exact locality (first record from that country).

\section{Adiantum latifolium Lam.}

Certain specimens, as, for instance, Mélinon 540, and Tulleken 423 from Surinam [U], are in general habit intermediate between A. latifolium and $A$. killipii. The internodes of the rhizome are shorter than in the first and longer than in the second-named species; in texture they are thinner than latifolium usually is and resemble in that respect the specimens of $A$. killipii I examined; but they differ from that species by the absence of the characteristic fibrils of the lower side. In aspect they agree with pl. 23 fig. 14 of Flora Brasiliensis Vol. I part II. I include them tentatively in $A$. latifolium, but they may represent a separate species or variety. They have often been called Adiantum intermedium Sw., e.g. in Flora Brasiliensis, l.c., but the true identity of this often misunderstood species was pointed out by Christensen (1910), p. 9.

\section{Adiantum melanoleucum Willd.}

A very large, at the base fully tripinnate, frond, without collector's name, number, or locality. It appears to be very much like $A$. urbanianum Brause, Fedde Rep. 15, p. 93, 1918/19, which I have not seen, referred to A. melanoleucum in Christensen's Index (suppl. I); perhaps it constitutes a distinct variety of this, although very variable, species. It has up to now not been recorded from the Guianas; as there is no label with indication of origin, one might doubt whether it really came from French Guiana. The matter is discussed at the end of this paper.

\section{Adiantum serrato-dentatum Willd.}

Some of the specimens of this species, which seems to be quite common in Guiana, e.g. Leblond 9, Leprieur 153 and 332, have partly larger pinnules (up to $11 \mathrm{~mm}$ long and $6 \mathrm{~mm}$ broad) with margins meeting under nearly right angles. They match exactly A. rectangulare Lindman (1903, p. 204; t. 9, fig. 3) from Matto Grosso. Lindman himself observed that "... Es ist möglich, dass diese Pflanze 
mit dem Ad. obtusum var. kunzei Miquel identisch ist". If this is true, Miquel's name has priority, as it has been published originally as a species (Miquel 1843, p. 189), and was only later reduced by Baker to a variety of $A$. obtusum (HOOKER-BAKER 1874, p. 119: $A$. obtusum, Desv.; ... $\beta$, A. Kunzei, Miquel ...). Lindman's name would therefore be superfluous. After having compared Miquel's type (Focke 86, Para, Surinam [U]) with Lindman's figure and description, I am certain that they are identical. The question then arises as to the status of this taxon. It is very near $A$. serrato-dentatum Willd. ( $A$. obtusum Desv.); although the type frond looks somewhat different by the crenato-lobate margins and the small number of segments per pinna (about 10), these are characters to be met with in otherwise typical $A$. serrato-dentatum, especially in sterile or incompletely fertile fronds. Moreover, Leblond 9 and Leprieur 153 contain other fronds which are indistinguishable from that species. Although these fronds are not actually attached to the same rhizome as those matching Miquel's $A$. Kunzei, it may be assumed that they belonged to one plant, since it would be quite fortuitous if they both consisted of a mixture of these two forms growing together. On the other hand, Lindman's (1903, p. 204) statement on A. obtusum Desv.: "Die Art scheint mir sehr konstant und monotypisch zu sein, weshalb ich keinen Anstand nehme, die folgende [A. rectangulare spec. nov.] als selbständige Art zu betrachten ..." is not to be neglected, as Lindman reported to have seen a large number of specimens of the first species. I prefer therefore to follow BAKER in treating A. kunzei as a variety of $A$. serrato-dentatum, which must then be called $A$. serrato-dentatum Willd. var. kunzei (Miq.) Kramer comb. nov. - A. kunzei Miq. (1843), p. $189 ; A$. rectangulare Lindman (1903), p. 204; A. obtusum Desv. var. kunzei (Miq.) Baker (1874), p. 119.

Another variety of this species, described as A. obtusum Desv. var. revolutum (errore: var. revoluta) by MiQuel (1.c.), p. 188 (Focke 611, Surinami ad Osembo in Para. Apr. 1842, type [U]) seems not to be separable from $A$. serrato-dentatum. It consists of a sterile and an incompletely fertile frond, where the few sori seem to be continuous by the revolute margin, which Miquel apparently mistook for "singulo dente soro semilunari". Posthumus cited the specimen under $A$. serratodentatum, in my opinion correctly.

\section{Adiantum tetraphyllum $\mathrm{H}$. B. Willd.}

As usually understood and construed here, this species is probably an aggregate. Moreover, I am not sure that even part of the specimens belong to the true $A$. tetraphyllum, as this species was described (WILldenow 1810 , p. 441): "... pinnulis oblongis, dimidiatis basi truncatis, margine superiore et apice oblique truncato...", and in all the Guiana material referred to this species that I examined the apices of the pinnules are rounded or somewhat narrowed, but never obliquely-truncate. Compare also Maxon's description (1926, p. 423): "...the fertile ones... the acutisch or acuminate tip; ... sterile pinnules... long acuminate, and falcate..." 
A form which is probably separable differs by its very dark colour of the leaf-tissue and in the pinnules being very close, contiguous or even overlapping, and evenly parallelogram-shaped; this is $A$. macrocladum Klotzsch sensu Jenman (1898, p. 89). It is remarkable that neither Jenman's nor Hooker's (1858, p. 49) descriptions agree entirely with the original one, nor with one another. Without knowing the variability of the species, nor having seen the type, I prefer to leave the solution of the matter to a monographer; all these forms are included here in A. tetraphyllum in its broadest and collective sense. Specimens seen: Leprieur 76, id. 264: "in sylvis montosis ad flumen Oyapok", and Sandwith 1567 from British Guiana, Mazaruni Station, called $A$. cayennense Willd., but with hardly incised margins; also no. 1088 from Surinam, without collector or locality (both U).

Key to the species of Adiantum of French and Dutch Guiana:

1. Veins free or occasionally anastomosing . . . . . . . 2 Veins copiously anastomosing; fronds herbaceous, with oblong pinnae . . . . . A. adiantoides (J. Sm.) C. Chr. (FG)

2. Rachis almost dichotomously branched (i.e. flexuose, with alternate pinnae, their rachises being nearly as strong as the main one) . . . . . A. leprieurii Hook. (FG, DG) Fronds simply pinnate ............. 3 Fronds bi- or tripinnate . . . . . . . . . . . 9

3. Midribs black at the base of the pinnae for $1 \mathrm{~cm}$ or more M. A phyllitidis J. Sm. (DG) Midribs with a very short black portion at the base or pale throughout or indistinct . . . . . . . . . 4

4. Lowermost pinnae with a very broad truncate-subcordate base, subsessile, $2-4 \mathrm{~cm}$ broad, subacute to shortly acuminate, mostly with a short black portion at the base of the midrib.

A. macrophyllum Sw. (DG) Lowermost pinnae narrower, or, if up to $2 \mathrm{~cm}$ broad, with a much narrower base and long-acuminate. Midribs everywhere pale or indistinct . . . . . . . . . . . 5

5. Petiole slender (0.3-0.5 $\mathrm{mm}$ at base of lamina); lamina ca. 6-12 cm long . . . . . . . . . . . . . . . . . . 6 Petiole strong ( $1 \mathrm{~mm}$ or more at base of lamina); lamina mostly longer . . . . . . . . . . . . . 7

6. Lamina with a large terminal pinna; lower surface glaucous .

A. petiolatum Desv. (FG, DG) Lamina without terminal pinna; rachis elongate, often rooting; Lamina withouti terminal pinna; rachis elongate, often rooting; lower surface not glaucous . . . A. deflectens Mart. (FG)

7. Sori continuous . . . . . . . . . . . . 8 Sori distinct . . . . A. obliquum Willd. (FG, DG)

8. Midrib median. Pinnae $2-3 \mathrm{~cm}$ broad, up to $5(-6)$ at a side. Veins mostly somewhat anastomosing. Lower base of pinnae often narrowed-rounded (fronds always simply pinnate) .. . 
Midrib mostly diagonal. Pinnae (or, in bipinnate fronds, pinnules) 1-2 cm broad, 6-18 at a side. Lower base of pinnae mostly narrowed-cuneate. Veins often completely free . . . . . . .

A. lucidum (Cav.) Sw. (FG, DG)

9. Sori continuous (or sometimes slightly interrupted by crinks of the margin). . . . . . . . . . . . . 10 Sori distinct . . . . . . . . . . . . . . . 13

10. Pinnules dimidiate . . . . . . . . . . . . . . . 12 Pinnules not dimidiate. . . . . . . . . . . 11

11. Pinnules elliptic to roundish, blunt; blades freely bipinnate; petiole up to $60 \mathrm{~cm}$ long. . . . A. oyapokense Jenm. (FG) Pinnules lanceolate, sometimes acuminate; only lowermost pinnae with a few free segments; petiole shorter

\section{A. lucidum (Cav.) Sw. (FG, DG)}

12. Sori on the basal half to two-thirds of the upper margin of the pinnules; these about $1 \mathrm{~cm}$ long

A. pulverulentum $\mathrm{L}$. (FG, DG) Sori on the upper and outer margin of the pinnules; these about $2 \mathrm{~cm}$ long . . . . . A. villosum L. (FG, DG)

13. Rachises glabrous; pinnules glaucous below ...... 14 Rachises more or less fibrillose-tomentose . . . . . . . 15

14. Sori deeply concavely curved; lamina often tripinnate at base A. melanoleucum Willd. (FG) Sori not or hardly concave; lamina bipinnate throughout . . . . . . . . A. glaucescens Kl. (FG, DG)

15. Pinnules with a distinct diagonal midrib ...... 16 Pinnules dimidiate, i.e. with the midrib running along the lower margin, or midrib very short or indistinct . . . . . . 17

16. Rhizome with long internodes; blades freely bipinnate $\cdot \cdot \dot{1}$ A. latifolium Lam. (FG, DG) ${ }^{1}$ ) Rhizome with short internodes: stipes clustered; blades with a few pinnate pinnae at the base. A. obliquum Willd. (FG, DG)

17. Apex of pinnae acuminate or acute; pinnae $1 \frac{1}{2}-3 \mathrm{~cm}$ long ... A. hirtum Splitg. (FG, DG) ${ }^{2}$ ) Apex of pinnae blunt or rounded, or pinnae shorter . 18

18. Rachises (at least the secondary ones) on both sides fibrillosetomentose. . . . . . . . . . . . . . 19 Rachises glabrous below, densely brownish-tomentose above; sori small; segments close . A. tomentosum Kl. (FG, DG)

19. Leaf-tissue of lower side bearing permanent hair-like, narrow fibrils . . . . . . . . . . . . . 20 Leaf tissue of lower side glabrous or glabrescent . . . 21

1 I cannot separate $A$. argutum Splitg., sometimes considered as a variety o A. latifolium; the type is in the Leiden herbarium.

2 Ienman (1898, p. 89) described a variety of $A$. macrocladum Kl. "with the margins deeply cut and the sori on the tips of the lobes, apart, like projecting beads along the margins, the pinnules being not rounded but much longer and acuminate, the colour equally dark.-Brasil and Peru." This I strongly suspect to be $A$. hirtum Splitg. 
20. Fibrils of lower surface numerous, yellowish; pinnules small, mostly about $1 \mathrm{~cm}$ long, often folded when dried; texture thin

A. terminatum Kze. (FG, DG) Fibrils of lower surface fewer, dark brown; pinnules larger; texture firmer . . A. killipii Maxon \& Weatherby (FG, DG)

21. Pinnules small, rhombic, parallelogrammic, or roundish, rigid to coriaceous . . . . . . . . . . . . . . . . 22

Pinnules oblong-lanceolate; texture soft, \pm herbaceous . . 23

22. Petiole rough; apex of fertile pinnules acutish or blunt; lamina often tripinnate at base . . . . A. cristatum L. (FG) Petiole smooth; apex of fertile pinnules rounded; lamina always bipinnate . . . . . A. serrato-dentatum Willd. (FG, DG)

23. Barren margin grossly crenato-dentate; sori on top of the crenations, separated by incisions

A. cayennense Willd. ex $\mathrm{Kl}$. (FG, DG) Barren margin serrate; sori on the margin, not separated by incisions . . A. tetraphyllum Willd. sens. lat. (FG, DG)

Asplenium haplophyllum Domin

Leprieur 109, without exact locality. This species was originally described (Domin 1929, p. 170) from Amazonian Brazil and British Guiana. Mr. G. V. Morton kindly informed me that, as far as he remembered, it has also been collected in Colombia. The specimen cited agrees very well with Domin's description and figure, the terminal segments being only somewhat more distinctly serratocrenate.

Bolbitis guianensis (Aubl.) Kramer comb. nov. - Polypodium guianense Aubl., Leptochilus guianensis (Aubl.) C. Chr., Lomagramma guianensis (Aubl.) Ching

This species was transferred to Lomagramma by CHing (Am. Fern J. 22, 1932, p. 17, not seen); Holtrum (1937, p. 196) showed that its proper place is in Bolbitis, not in Lomagramma. As he did not make the new combination, it will be necessary to do so here. Specimen examined: Leprieur s.n., 1836, "in sylvis paludosis truncis arborum scandens ad ripas Juipi et Inini".

\section{Bolbitis semipinnatifida (Fée) Alston}

Mélinon 364, 1842, without exact locality. Not previously known from French Guiana, but recently collected in Surinam, and, according to Alston (1932, p. 310), known from British Guiana, Trinidad, and Venezuela.

A specimen labelled only " 367 " belongs either to this species or to $B$. aliena (Sw.) Alston.

\section{Dennstaedtia ordinata (Klf.) Moore}

Leprieur ..133, without further data. The rather fragmentary material, consisting of pinnae or parts of them, and pieces of rachises, was identified with MAxoN's key (1926, p. 491), and agreed well 
with material from Venezuela in the Leiden herbarium. It is therefore fairly certain that it belongs to this species, characterized by sessile pinnae and pinnules, more or less truncate segments, and the pubescence of rachises and costae. It is noteworthy that no other species of the genus has ever been collected in the Guianas, except D. adiantoides (H. B. Willd.) Moore cited by Posthumus (p. 68) also from French Guiana, which I did not see. Posthumus might have mistaken $D$. ordinata for $D$. adiantoides.

Diplazium arboreum (Willd.) Pr.

Maxon is followed here in uniting this species with D. shepherdii (Spr.) Link. Leprieur 45, without locality.

\section{Diplazium expansum Willd.}

Leprieur 117 (the herbarium label of Paris bears the number 353) and 43, both without further data. Greater Antilles, Northern South America to Brazil, but not previously known from Guiana. Possibly an aggregate, as was pointed out by MAxon (1926, p. 443).

\section{Diplazium celtidifolium Kze.}

The specimens which are placed here in this species show a very wide range of variation. Several of them: Leprieur 62, 116, 343, and an unnumbered collection "les bords de l'Oyapok vers ses sources" have relatively short fronds with short (up to $9 \mathrm{~cm}$ ), coriaceous pinnae, the lower ones abbreviated and deflexed, some of the fertile ones being only $1 \frac{1}{2} \mathrm{~cm}$ broad, with nerves once or twice forked, and predominantly or even entirely diplazioid sori. The sterile fronds of Leprieur 116 are peculiar in having pinnae with a truncate base (in a right to acute angle) above, this being more oblique in the lower ones, but also hardly rounded; but other fronds on the same rhizome show the shape which is characteristic in other Guiana specimens, with a rounded, often slightly auricled upper base with the margins meeting under an angle larger than $90^{\circ}$. If it were not for these fronds being attached to the same rhizome, one would be inclined to take them for two or even three different species. They are more coriaceous than usual, but represent possibly only a form of a dry and/or sunny habitat of $D$. celtidifolium in a broad sense. Another frond labelled only "Cayenne" approaches in texture and shape of pinnae D. grandifolium (Sw.) Sw., but is also referred here to $D$. celtidifolium, until a monographic treatment of this very complex group elucidates the status of all the forms.

Dryopteris (Glaphyropteris) decussata (L.) Urb.

Ghristensen (1913), p. 160, and Posthumus (1.c.) p. 43 cite a collection of Leprieur without further data. An additional specimen is Leprieur, 1847, s.n. "ad torrentes montis Tibourou". These are apparently the only collections of this species from the Guianas.

\footnotetext{
Dryopteris (Ctenitis) protensa (Afz.) C. Chr. var. dicksonioides (Fée) C. Chr.
} 
A second specimen besides that cited by Christensen (1920), p. 93, and Posthumus, is Leprieur (?) 108. The var. funesta (Kze.) G. Chr. is much more common in Guiana.

Dryopteris (Stigmatopteris) sancti-gabrieli (Hook.) O.Ktze.

Leprieur 41, "in sylvaticis confertis montium guyanae centralis summo". Not previously known from French Guiana, but collected in British and Dutch Guiana, and besides in Amazonas, Trinidad, and Venezuela.

Dryopteris (Goniopteris) subtetragona (Link) Maxon

Leprieur without data, 1838, id. 183, without loc., ip.p. Not previously reported from French Guiana.

Elaphoglossum glabellum J. Sm.

Leprieur 50. Posthumus cited this species without having seen a specimen, only quoting Fée.

Elaphoglossum longifolium (Jacq.) J. Sm.

Leprieur (?) 122, without data. Not previously known from French Guiana. For the name of this species, that has often been called E. rigidum (Aubl.) Urb., see Alston (1932), p. 316.

Elaphoglossum schomburgkii (Fée) Moore

Leprieur 241, 242, 243, "ad truncos vivos arborum riparum summo fluminis Oyapok". This species is construed here in its broadest sense, as I am not able to draw good border lines between the closely allied forms; it includes the specimens from Surinam named E. pteropus C. Chr. by Posthumus, p. 151, which they are certainly not. The cited collections belong to the form called $E$. luridum (Fée) Christ by Christ (1899). The true

Elaphoglossum pteropus G. Chr.

has also been collected in French Guiana: Leprieur s.n. "in truncis arborum, in sylvis aeternis ad amnem Gabaret"; it is as yet not known from Surinam.

Eschatogramme desvauxii (Kl.) G. Chr.

All the Surinam specimens, which were included by Postrumus in E. furcata (L.) C. Chr., belong to this species. The same is true for the French Guiana specimens seen: Mélinon 383, Leprieur 103.

Nephrolepis exaltata (L.) Schott

Posthumus apparently has not seen any material from French Guiana, as he cites (l.c., p. 66) only a reference to Aublet. Specimen examined: Leprieur 34, "stipitibua palmarum ad tipas Oyapok".

Polypodium (P.) dissimile L.

Leprieur 92. Not previously known from French Guiana, but 
collected in Surinam, and, according to Alston (in litt.), in British Guiana.

\section{Polypodium (Microgramma) fuscopunctatum Hook.}

Leprieur 77, without loc. The first record of this species from French Guiana; but, as one of the specimens from Surinam cited by Posthumus under $P$. thurnii Bak. really belongs to $P$. fuscopunctatum, it might have been overlooked. Apart from several other collections from Surinam, it is known from British Guiana and Ecuador (the type locality). Cav.)

Polypodium (Campyloneuron) lapathifolium Poir. (laevigatum auct. non

Leprieur 81, without exact locality. Not previously recorded from the Guianas.

Polypodium (Phlebodium) leucatomos Poir. (decumanum Willd.)

Leprieur (?) 93, without loc. The specimen (part of a lamina in a rather poor state) has distinctly laxly undulate-crenate margins and may belong to a distinct variety.

Polypodium ("Ctenopteris") mollissimum Fée

Leprieur s.n., "corticibus arborum ad ripas amnis Inipi"; not previously known from French Guiana, but, as MAXON \& Morton (1948), p. 77, pointed out, probably confused by Posthumus with $P$. cultratum Willd.

Polypodium (P.) plumula H. \& B. ap. Willd.

Leprieur (?) 95. Not yet recorded from French Guiana; included by Posthumus in $P$. hygrometricum Splitg.

Polypodium (Marginaria) polypodioides (L.) Watt

All the Guiana material seems to belong to the var. burchellii (Bak.) Weatherby from tropical South America. Leprieur 535, id. (?) 101, Rech 12.

Polypodium (Xiphopteris) trichomanoides Sw.

Posthumus united three species under this name: $P$. taenifolium Jenman, $P$. nanum Fée and $P$. trichomanoides Sw. s. str. The latter is in South America only known from French Guiana (collections examined: Rech 38, Leprieur s.n. "summo arborum muscis intermixtum in sylvis humidis Oyapok superius", a mixture with $P$. taenifolium and nanum), its area being predominantly West-Indian. The material from Surinam belongs to the two other species respectively. Another collection of

Polypodium nanum Fée

is Leprieur (?) 140. For the differences between the three species see Maxon (1913) and Copeland (1952). 
Polytaenium brasilianum (Desv.) Bened.

Posthumus included this species in his key of "Anthrophyum", but did not give any further data. Leprieur 110, "ad truncos arborum, in sylvis ad ripas amnis Yavé adnatum".

Polytaenium jenmani (Bened.) Bened.

This species, which was described by Benedict (1907) as Antrorhyum and later transferred by him to Polytaenium, has been neglected by Posthumus. Benedict cited as a cotype the specimen I saw : Leprieur 109, "rupibus humidis, in sylvis umbrosis circa Tacourou Epirok sitis in guyanae centrali"'.

Pteridium aquilinum (L.) Kuhn ssp. caudatum (L.) Bonap.

When identifying the material with TRYon's key (1941), I became convinced that two specimens (Leprieur 56, and one without data) belong to the var. caudatum rather than to var. arachnoideum (Klf.) Herter, to which up to now all Guiana material was referred, whereas one specimen (Leprieur 121) is intermediate between the two varieties. The first has, according to TRYON, a circum-caraibic area, its easternmost station on the continent of South-America lying in Western Venezuela, whereas the second is very widespread in tropical America; to this belongs Leprieur 55.

Pteris altissima Poir. (kunzeana Ag.)

Posthumus did not see material from French Guiana. Leprieur (?) 57, without further data, and 101, "in paludosis ad basin montium guyanae centralis".

Pteris biaurita $\mathbf{L}$.

Martin s.n., Cayenne, p.p.; Leprieur 99, "in sylvis humidis herbosis ad ripas rivuli Cacao, amnis la Comté"; Leprieur 119 and 120, without localities.

Pteris quadriaurita Retz.

Martin s.n., Cayenne, p.p.

This species, construed here in a rather broad sense, is a new record from French Guiana.

\section{Vittaria gardneriana Fée}

Leprieur 125, without exact locality; 145, id., and 103, "ad truncos arborum in sylvis guyanae centralis ad amnem Erepousinghe". Identified with Benedict's key (though the fronds are very short; up to $9 \mathrm{~cm}$ in one, up to $15 \mathrm{~cm}$ in another specimen) I am convinced it belongs here. Mr. C. V. Morton confirmed my opinion. BenEdict cited it from Mt. Roraima in British Guiana; it is not known from Surinam. 


\section{Parkeriaceae}

\section{Ceratopteris.}

Postrumus, who overlooked Benedict's preliminary revision of the genus (1911), called all specimens $C$. thalictroides (L.) Brongn. I saw the following species from French Guiana:

C. deltoidea Bened. Leprieur 39.

C. pteridoides (Hook.) Hieron. Leprieur (?) 380; id. 19.

An unnumbered specimen belongs perhaps to C. thalictroides (L.) Brongn. s. str., but this is not certain, as it is sterile. The last-named species, mentioned by BENEDICT in the New World from Jamaica only, seems to be more widespread; it was collected several times in Surinam.

The fourth species recognized by BENEDICT, C. lockharti (Hook. \& Grev.) Ktze., and mentioned by him from French Guiana, was not present in the material at my disposition.

\section{Cyatheaceae}

Cyathea circumdentata Kramer nom. nov. - Hemitelia leprieurii Jenman (1898), p. 47, non Kunze, which is Cyathea leprieurii (Kze.) Domin, Pteridophyta (1929), p. 264 (not seen), considered a synonym of Cyathea (-Hemitelia) spectabilis (Kze.) Domin by Posthumus.

This species is, in my opinion, not closely allied to $C$. macrocarpa (Pr.) Domin, as was stated by Postrumus, but nearer to $C$. multiflora J. Sm., near which it was placed by JENMAN, although he states: "this is a very distinct species from multiflora...", the most conspicuous difference being the very distinctly crenate-serrate margins of the segments.

An additional specimen, besides the type, which $I$ have not seen, is Poiteau, without number or locality, 1824; it differs from Jenman's description only by the presence of very short and small strigose hairs on veins and leaf tissue of the lower side. In this respect it agrees with a specimen from British Guiana (A. G. Smith 2873), identified by Mr. C. A. Weatherby. As these hairs give the impression of being somewhat caducous, JENMAN may not have found them.

\section{Cyathea escuquensis (Karsten) Domin}

Leprieur, without number or locality. The material differs from Karsten's description by the presence of (more) numerous bullate scales on the costules below; from Maxon's (1926, p. 388) by the absence of glandular pubescence below, which is, however, not mentioned by KARSTEN. Size, cutting, indusia, spores, and paraphyses agree well with KarsTEN's description and figures. The species was not yet known from Guiana; it was described from Western Venezuela, and later reported from Puerto Rico. 
Cyatha multiflora J. Sm.

According to Alston (1932, p. 308), Posthumus misinterpreted this species; he segregated Hemitelia guianensis Hook. I am not able to give a judgment on the problem, so I keep the material concerned provisorily under this name. Anyhow, the combination Cyathea guianensis is already preoccupied by $C$. (Alsophila) guianensis (Regel) Domin, (1930), p. 120.

Cyathea parkeri (Hook.) Kramer, comb. nov.

In accordance with Alston (1932, p. 308), this is regarded as a separate species. When Alsophila and Hemitelia are sunk in Cyathea, a new specific epithet becomes necessary, as Alston's name Hemitelia strigosa (J. Sm.) Alston is not available because of $C$. strigosa Christ 1897. The oldest name is Alsophila weigeltii Roemer ex Presl, 1836, but this was published as a nomen nudum. Therefore the epithet parkeri Hooker 1844 should be used.

\section{Hemitelia hirsuta (Desv.) Weatherby}

Leprieur s.n., "in sylvis umbrosis, ad amnem Conana secus rivulos, 1847 ". Identified by comparison with excellent material from British Guiana, (leg. A. C. Smith), named by Weatherby. Probably not previously known from French Guiana. When transferred to Cyathea, the species needs a new specific epithet, as its name is preoccupied in that genus by $C$. hirsuta Pr. (= armata (Sw.) Domin = Alsophila swartziana Mart.) and C. hirsuta Bak. (= hirsutifrons C. Chr.). Without having seen the type, nor Weatherby's paper containing the new combination in Hemitelia, I abstain from renaming the species.

Dubious specimens:

Several specimens could not be named satisfactorily. Leprieur 205 belongs to what is called the group of Alsophila armata Pr.; Sampaio's key (1925) leads to that species. That is, however, restricted to Jamaica and Cuba; the name armata, too, is incorrect, as was shown by MAxON (1922). There are several closely allied species of the group in South America, but I could not identify the material with one of them. The same holds for Mélinon s.n., Cayenne; this is probably the species of Sampaio's pl. 18. Both species are evidently new for the flora of French Guiana.

\section{Marattiaceae}

Danaea nodosa (L.) J. E. Sm.

Mr. C. V. Morton drew my attention to the fact that the material from Surinam called $D$. elliptica $S w$. belongs really to $D$. nodosa, characterized by its nodose rachis and nodeless petiole. Specimens from French Guiana are Leprieur s.n., 1838; Leprieur 275, cited by Posthumus under $D$. elliptica, presumably belongs also to $D$. nodosa. 
General remarks.

Among the species not previously known from French Guiana, the most outstanding are Adiantum cristatum L. and $A$. melanoleucum Willd., as these species are otherwise entirely West-Indian in their distribution. One might doubt the correctness of the locality; as the labelling in those days often was, and in the specimens concerned actually is, very incomplete, one might assume that the locality French Guiana is incorrect; they could for instance have been collected on French West-Indian islands, which doubtless have often been visited by the same ships that sailed to or from Guiana. This is probably true for two sheets belonging to Dryopteris (Ctenitis) subincisa (Willd.) Urb., bearing neither number nor locality; this species has never been collected in the Guianas, but it is known from Trinidad, whose flora is more akin to that of the Guianas than that of the other Lesser Antilles; but at present it seems better not to include it in the fern flora of French Guiana. I do not think, however, that the same should be assumed in the case of the two Adiantum's; there are, in fact, not a few fern species in the Guianas whose distribution is predominantly or entirely West-Indian, but whose indigeneousness in the Guianas is not to be doubted, e.g. Polypodium trichomanoides Sw. and P. taenifolium, Cyathea pungens (Willd.) Domin, Paltonium lanceolatum (L.) Pr., etc. As far as I could ascertain, these species are, at least in Guiana, entirely montane.

I wish to express my sincerest thanks to Mme $M$. Tardieu-Blot and Prof. H. Humbert for sending me the collection (almost 500 specimens) on loan, to Mr. C. V. Morton for his helpful and critical remarks on some dubious specimens, and to the Director of the Leiden Herbarium for lending me valuable material for comparison.

\section{REFERENCES}

Alston, A. H. G. 1932. Contributions to the flora of tropical America XIII. Pteridophyta collected by the Oxford Expedition to British Guiana, 1929. Kew Bull.

BAKer, J. G. 1870. Cyatheaceae and Polypodiaceae, in Flora Brasiliensis I², Monachii.

BENEDICT, R. C. 1907. The genus Antrophyum. I. Synopsis of subgenera, and the American species. Bull. Torr. Bot. Cl. 34 .

BenEdict, R. C. 1909. The genus Ceratopteris: a preliminary revision. Contr. N.Y. Bot. G. 126; (Bull. Torr. Bot. Gl. 36).

Benedict, R. C. 1914. A revision of the genus Vittaria J. E. Smith. I. The species of the subgenus Radiovittaria. Contr. N.Y. Bot. G. 171 (Bull. Torr. Bot. Cl. 41).

Christ, H. 1899. Monographie des Genus Elaphoglossum. Zürich.

Christensen, G. 1909. Ueber einige Farne in O. Swartz' Herbarium. Ark. f. Bot. $9: 11$.

Christensen, C. 1913, 1920. A monograph of the genus Dryopteris. Part I: The tropical American pinnatifid-bipinnatifid species. København. Part II: The tropical American bipinnate-decompound species. København.

Copeland, E. B. 1952. The American species of Xiphopteris. Am. Fern. J. 42 : 2 and 3.

Domin, K. 1929. The Pteridophyta of the island of Dominica, with notes on various ferns from tropical America. Praha.

Domin, K. 1930. The species of the genus Cyathea J. E. Sm. A preliminary list. Acta Bot. Boh. 9. 
Holtrum, R. E. 1937. The genus Lomagramma. Gardens' Bull. 9 : 2.

Hooker, W. J. 1858. Species Filicum, vol. II.

HOOKer, W. J. \& J. G. BAKer. 1874. Synopsis Filicum (2nd ed.).

Jenman, G. S. 1898. The ferns and fern-allies of the British West Indies and Guiana, 1. Trinidad.

KaRsTeN, H. 1862-1869. Florae Columbiae terrarumque adiacentium specimina selecta. Vol. II.

Lindman, C. A. M. 1903. Beiträge zur Kenntnis der tropisch-amerikanischen Farnflora. Ark. f. Bot. 1.

Maxon, W. R. 1916. Polypodium trichomanoides and its allies. Contr. U.S. Nat. Herb. 87: 7 .

Maxon, W. R. 1922. The North American species of Alsophila grouped with A. armata. Contr. U.S. Nat. Herb. 24: 2.

Maxon, W. R. 1926. Pteridophyta of Porto Rico and the Virgin Islands.

Maxon, W. R. \& C. V. Morton. 1948. Pteridophyta, in: B. Maguire, Plant explorations in Guiana 1944, etc. Bull. Torr. Bot. Cl. 75.

Miquel, F. A. G. 1843. Observationes botanicae de quibusdam plantis, quas in Colonia Surinamensi legit vir graviss. H. C. Focke. Versl. en meded. uitgeg. d. h. Kon. Ned. Instit. v. Wetensch. ("Het Instituut").

Posthumus, O. 1928. The ferns of Surinam and of French and British Guiana. Malang.

Sampaio, A. J. DE. 1925. Contribucões para a nova Flora Brasiliense. O. Gen. Alsophila $\mathrm{R}$. Br. (1810) na flora brasileira (Cyatheaceas). Arch. Mus. Nac. Rio de Janeiro 25.

Tryon, R. M., Jr. 1941. Revision of the genus Pteridium. Contr. Gray Herb. 134. Wruldenow, G. L. 1810. Species Plantarum V., Berolini. 